In the iron and steel industry there is scope for chemists, physicists, metallurgists and engineersprovided that they have the gift of establishing human relations. In industry, the understanding of one's fellow men is more important than technical knowledge. Sir William decried the modern pose that enthusiasm is 'bad form'. We live in an age of great difficulties and responsibilities, but also of great possibilities-and we need all the enthusiasm that we can muster.

\section{Flora of East Anglia}

"rHE East Anglian Flora-a Study in Comparative Plant Geography" is the title of the presidential address by Prof. E. J. Salisbury to the Norfolk and Norwich Naturalists' Society, reprinted from the Society's Transactions (vol. 13, pt. 3, 1932, pp. 191-263).

While treating specially of the flora of East Anglia, Prof. Salisbury has extended the scope of his address to include a survey of the major problems of geographical distribution in Great Britain as a whole. Eight components are recognised in the British flora, four of which are further subdivided into eleven constituent elements, and stress is laid upon the importance of viewing these groups in relation to the distribution of the species on the continent of Europe. The largest components are the southern, the oceanic and the continental. The majority of the southern species exhibit in Britain a diagonal limit running in the south-west-north-east direction, indicative of their comparative intolerance of oceanic conditions, while in contrast to these, most of the oceanic species show a diagonal limit passing in a south-east-north-west direction. The continental component includes the steppe species, many of which are located in East Anglia, and it is held that their occurrence there is correlated with a combination of low rainfall and favourable edaphic conditions.

Two strikingly contrasted climatic areas are found in the East Anglian region, in which marked difference in rainfall is accentuated by differences of soil and topography, resulting in the juxtaposition of both continental and oceanic species. The general conclusion is reached that climate is the most important factor determining the distribution of plants in Britain, though evidence is adduced in certain cases to show that soil preferences and the competition factor may act as modifying influences.

A noteworthy feature of the paper is the large number of maps, 106 in all, clearly illustrating the range of individual species within the British Isles, while numerous photographs are included depicting certain interesting species in their natural habitats. Copies of the paper (price 5s.) may be obtained from Dr. S. H. Long, 31, Surrey Street, Norwich.

\section{University and Educational Intelligence}

BirminghaM.-The annual meeting of the Court of Governors on February 23 presided over by the Chancellor (Viscount Cecil of Chelwood) was marked by a general feeling of regret at the retirement from the Council of Mrs. C. G. Beale (widow of the first Vice-Chancellor) and the resignation of his office as Pro-Chancellor by Sir Gilbert Barling after many years of highly valued service to the University. Mr. Walter Barrow was elected Pro-Chancellor and, after the Chancellor had signified his approval of the election, Sir Gilbert Barling rose from his seat and divested himself of his robes of office saying that these robes, originally worn by the first ViceChancellor, had been given to him by Mrs. Beale when he succeeded to the vice-chancellorship. Sir Gilbert now desired, with Mrs. Beale's approval, to present them to the University and he proceeded forthwith to invest with them the new Pro-Chancellor. The Chancellor paid a tribute to Sir Gilbert Barling, whom he described as a man possessed of a great faculty which he could only describe as the faculty of being right. His advice was always to be trusted.

Sir George Kenrick moved a resolution in which the Court gratefully acknowledged the services of the retiring Pro-Chancellor as demonstrator in anatomy in Queen's College in 1885, as professor of pathology in 1886-1893, joint professor of surgery in 1893-1913, dean of the Faculty of Medicine in 1905-1912, member of the Court of Governors since 1900 and of the University Council since 1903, as ViceChancellor and chairman of Council in 1913-1927 and Pro-Chancellor from 1927 until the present time. Prof. F. W. Burstall in seconding the resolution paid a tribute on behalf of the academic side of the University. The dean of the Faculty of Medicine (Dr. Stanley Barnes) spoke in very warm and appreciative terms of Sir Gilbert whom he characterised as a great surgeon, a great teacher and a great administrator.

The title of emeritus professor was conferred on Prof. W. S. Boulton (geology and mineralogy) and Prof. J. T. J. Morrison (forensic medicine and toxicology).

Cambrmar.-A University demonstrator in geography will shortly be appointed. The duties will commence on April 1. Particulars can be obtained from Prof. F. Debenham, at the Department of Geography, to whom applications should be sent on or before March 7 .

The Balfour studentship in biology has been awarded to F. R. Parrington of Sidney Sussex College.

It has been recommended that the plans prepared by Sir Herbert Baker for the Scott Polar Research Institute be approved.

Edinburgh.-His Majesty the King in Council has approved of the ordinance providing for the affiliation of the Heriot-Watt College to the University.

Prof. Heinrich Wieland, of the University of Munich, has been invited to give the first Romanes lecture. These lectures are provided from an endowment fund in memory of Dr. Robert Romanes, and James Manners Romanes, brother of the late Miss I. D. Romanes. Part of the endowment is used to bring distinguished chemists from other centres to lecture in Edinburgh.

London.-His Majesty the King, who will be accompanied by the Queen, will lay the foundation stone of the new University buildings on June 26.

The following appointments have recently been made: Prof. J. B. S. Haldane, since 1922 reader in biochemistry in the University of Cambridge and since 1927 head of the Genetical Department at the John Innes Horticultural Institution, to be professor of genetics at University College; Mr. W. P. Yetts, lecturer in Chinese art and archæology at the Court auld Institute of Art, to be professor at the Institute; Prof. Cyril L. Burt, to the Heath Clark lectureship for 1933 . 